\title{
Evaluation of the impact of chemical control measures and entomological surveillance on Chagas' disease in the counties of Mambaí and Buritinópolis, Goiás State, Brazil
}

\author{
Avaliação do impacto das ações de controle químico e vigilância entomológica da doença de \\ Chagas nos municípios de Mambaí e Buritinópolis, Estado de Goiás, Brasil
}

\author{
Antonio Carlos Silveira1, Rosaura Peñaranda-Carrillo', Elias Seixas Lorosa ${ }^{2}$, João Leite ${ }^{3}$, \\ Márcio Costa Vinhaes ${ }^{3}$, Cleudson Castro ${ }^{1}$, Aluízio Prata ${ }^{1}$ and Vanize Macêdo ${ }^{1}$
}

\begin{abstract}
Epidemiological surveillance activities were implemented in 1980 in Mambaí and Buritinópolis counties, Goiás State. Twenty years later the authors evaluated the impact of these vector control measures on Chagas' disease transmission, based on entomological indicators. Entomological investigation was conducted using the man-hour technique and covering all domiciles. In order to study vector food sources the stomach contents of triatomines were analyzed using the modified precipitins technique. Triatomines were shown to be present in 48 (71.6\%) of the 67 locations. Peridomiciliary infestation rates in Mambaí and Buritinópolis were $8.7 \%$ and 12.1\%, respectively, while intradomiciliary rates were $0.7 \%$ and $1.2 \%$. Triatoma sordida was the species identified in 97.3\% of all captured specimens. It was also the only species found to be naturally infected with Trypanosoma cruzi. Birds were the most frequent food source $(45 \%)$ for Triatoma sordida. The most significant result was the complete absence of Triatoma infestans in the two counties.
\end{abstract}

Key-words: Chagas' disease. Entomological Surveillance. Triatoma infestans. Domiciliary unit. Vectors.

Resumo Em 1980, foram implantadas as atividades de vigilância epidemiológica em Mambaí/Buritinópolis (GO). Vinte anos após buscamos avaliar o impacto dessas ações sobre a transmissão da doença de Chagas, com base em indicadores entomológicos. A pesquisa entomológica foi feita, pela técnica horahomem, alcançando todas as unidades domiciliares. Para o estudo de fontes alimentares foi analisado o conteúdo estomacal dos triatomíneos através da técnica de precipitinas modificada. Em 48 (71,6\%) das 67 localidades comprovou-se a presença de triatomíneos. Os índices de infestação peridomiciliar em Mambaí correspondem a 8,7\% e 12,1\% em Buritinópolis e com taxas para o intradomicilio de 0,7\% e 1,2\% respectivamente. Triatoma sordida foi a espécie identificada em $97,3 \%$ das capturas. Esta foi a única espécie que se comprovou naturalmente infectada pelo Trypanosoma cruzi. As aves constituíram-se na fonte alimentar mais freqüente (45\%) do T. sordida. O resultado mais significativo foi a completa ausência de Triatoma infestans nos dois municípios.

Palavras-chaves: Doença de Chagas. Vigilância entomológica. Triatoma infestans Unidade domiciliar. Vetores.

Work began on Chagas' disease in the county of Mambaí, Goiás State, in 1973, with a geographical survey of the area (a new population census and mapping of domiciles and roads/paths). Investigation per se began in 1975. Over the course of 15 months, a total of 3,150 individuals were submitted to clinical, radiological, electrocardiographic and serological examination, with the simultaneous collection of epidemiological data from approximately 900 residential units $^{23} \cdot$ In 1975, a triatomine survey was also performed in all the domiciliary units (DUs), 455 of which were surveyed again in 1979, when an increase was observed in intradomiciliary infestation by Triatoma infestans, from $52 \%$ in 1975 to $74 \%$ in $1979^{13} 14$.

The initial survey recorded house construction materials, spatial organization, hygiene, socioeconomic conditions, and perception of Chagas' disease among the local population, seeking to correlate these variables with the presence of triatomines colonizing the domiciles ${ }^{12}$.

According to the 1979 census performed by the University of Brasilia team, the entire county of Mambai had 4,549 inhabitants, with 906 residing in the county seat. As for the number of domiciles, in 1979 there were 137 urban buildings and 739 dwellings in the rural area ${ }^{2}$.

\footnotetext{
1. Núcleo de Medicina Tropical da Universidade de Brasília, Brasília, DF. 2. Departamento de Biologia da Fundação Oswaldo Cruz, Rio de Janeiro; RJ. 3. Fundação Nacional de Saúde.

Address to: Dra. Vanize Macêdo. Núcleo de Medicina Tropical e Nutrição/UNB. Caixa Postal 4517, 70919-970 Brasília, DF.

Fax: $5561273-2811$

e-mail: tropical@unb.br

Recebido para publicação em 21/6/2001.
} 
In 1980 the Superintendency for Public Health Campaigns (SUCAM/Ministry of Health) conducted insecticide spraying of buildings (benzene hexachloride, $\mathrm{BHC}, 30 \%$ of active ingredient) with a full coverage of the area. Some 465 domiciles located on one side of the main highway cutting across the county were sprayed only once, while 221 domiciles located on the other side of the road were sprayed twice. Epidemiological surveillance activities were implemented immediately afterwards by teams from the University of Brasilia (UnB) and SUCAM and community participation was included ${ }^{912}$.

A clinical review was performed on 1,400 individuals in 1980-82 and approximately 1,600 in 1986-91. Part of the adult population and some infected children were submitted to specific chemotherapy. Measures also included xenodiagnosis of a major portion of the population, radiological investigation of the intestinal tract in various adults, and serological and parasitological tests in children born after vector control began ${ }^{23}$.

A new selective spraying of infested domiciles was conducted in 1981, after surveillance activities had begun. Surveillance coverage was complete at first, reaching all 58 localities in the county, but beginning in 1993 only 37 of what were considered especially vulnerable localities were kept under entomological monitoring ${ }^{8912}$.

Epidemiological surveillance methods implemented in Mambaí from 1981 to 1992 consisted basically of local residents' notification of the presence of triatomines in their houses, which was followed by man-hour investigation by trained public health agents, using manual capture and insectifuge (liquid butopyronoxyl, Pirisa $\left.^{\text {TM }}\right)^{81214}$. This work was accompanied by inspection of the Gómez Núñez boxes and calendars in order to identify vestiges or even to collect triatomines in plastic bags that came with the calendars. New Surveillance Units (SUs) or Minimal Surveillance Units (MSUs) as well as Peridomiciliary Surveillance Units (PSUs) were installed ${ }^{914}$. Whenever infestation was demonstrated, the domiciliary unit was sprayed again with residual insecticide, regardless of the vector species, place of capture, or triatomine stage. The term SU was used to refer to the kit including the Gómez Núñez box, calendar, and plastic bag. This kit was replaced once a year ${ }^{13}$.

In 1984 the so-called Triatomine Information Centers (TICs) were also set up with community leaders, schools, and other local services to which the local populace could refer when they found triatomines, while four more remote locations received Triatomine Information and Attack Centers (TIACs). The leaders in charge of these centers were chosen by the community and were in charge of covering 20 to 25 domiciles.

$\mathrm{BHC}$ was the only insecticide used until the first semester of 1983, when spraying began with synthetic pyrethroids, generally deltamethrine at a concentration of $0.05 \mathrm{~g}$ active ingredient $/ \mathrm{m}^{2}{ }^{12}$. Exceptionally, in early 1984,22 domiciles were sprayed with malathion at $2.5 \mathrm{~g} /$ $\mathrm{m}^{2}$ due to a temporary lack of pyrethroids. Triatomine searches in domiciliary units were performed separately by the SUCAM and UnB teams, but the spraying work was carried out exclusively by SUCAM, except in those locations where TIACs were set up in $1984^{9}$.

Of the 1,041 residential units in 1980,724 were surveyed for the long-term effect of insecticides, while the number of domiciles investigated decreased year by year according to the historical data presented in Table $1^{9}$.

Table 1 - Number of triatomine specimens captured, by species (Triatoma infestans and Triatoma sordida) according to place of capture in the county of Mambaí, Goiás State, Brazil. 1980 to 1984.

\begin{tabular}{lccccc}
\hline & & \multicolumn{4}{c}{ Number specimens captured } \\
\cline { 3 - 5 } Year & Nr. DUs inspected & \multicolumn{2}{c}{ intradomicile } & \multicolumn{2}{c}{ peridomicile } \\
\cline { 3 - 5 } & 724 & 207 & 32 & 9 & 57 \\
1980 & 695 & 94 & 23 & 4 & 47 \\
1981 & 563 & 131 & 31 & 3 & 56 \\
1982 & 580 & 99 & 28 & 19 & 62 \\
1983 & 570 & 81 & 32 & 8 & 62 \\
1984 & & & & & \\
\hline
\end{tabular}

DUs: domiciliary units

In addition to $T$. infestans and $T$. sordida, the predominant species at the time, other triatomines captured in the county in decreasing order were as follows: $R$. neglectus and $P$. megistus in the intradomicile and T. pseudomaculata in the peridomicile. A few specimens of $T$. costalimai and $P$. diasi were also identified ${ }^{814}$.

Notification by dwellers was responsible for $60 \%$ of identification of infested domiciles, while manual capture and Gómez Núñez boxes proved to be relatively ineffective. Among the positive Gómez Núñez boxes,
$70 \%$ contained vestiges (feces), while only $8 \%$ contained either adult or nymphal triatomine specimens ${ }^{8}$.

Evaluation of the program's efficacy from 1980 to 1984 showed that by 1984 the intradomiciliary infestation with $T$. infestans had decreased significantly, but that peridomiciliary infestation with $T$. sordida had persisted ${ }^{9}$.

Analysis of data for 271 intradomiciles monitored from the beginning of the work in the area until 1984 showed that high density rates for $T$. infestans $(25$ triatomines /house) - which in 1980 represented $15.7 \%$ 
of the infested domiciles - were no longer observed, and that even domiciles with so-called average rates (11 to 24 triatomines/house), which had represented $9.9 \%$ of the total in 1980 , were no longer observed either. During the pre-spraying phase, an average of 14.3 triatomines/house were captured, while by 1984 this figure had dropped to some 1.6 triatomines/house. Notification of $T$. infestans collected in plastic bags in 1981 was 13.5 specimens/house, while by 1984 it was only 1.2 per house 8914 .

Beginning in 1985, the county had 48 triatomine collection posts, in addition to the coordinating center in the county seat of Mambaí, 21 TICs, 5 TIACs, and 21 primary health care clinics. These units were visited twice a month. From 1985 to 1988 , a total of 2,070 DUs were investigated, of which $1,754(84.7 \%)$ were searched, with some proven type of triatomine infestation found in 419 $(20.3 \%)$. Mean annual infestation was $23 \%$. In terms of the predominant vector species, $T$. sordida was found in 323 and T. infestans in only 33 , while in 48 other DUs only vestiges were found. Beginning in 1988, T. infestans was no longer captured in the area, and since then it has been found only sporadically, presumably due to external reinfestation. During this period (1985-88) a total of 1,075 specimens were captured: 963 T. sordida, 69 T. infestans, and 43 from all other species combined. The natural infection rates for Trypanosoma (type) cruzi were $7.5 \%$ for $T$. infestans, $1.4 \%$ for $T$. sordida, and zero for other species. In 1987-88 no infected specimen was found ${ }^{89}$.

With regard to reporting of triatomines by local inhabitants themselves, during 1985-88 a total of 962 notifications were made, and 248 of the insects collected in plastic bags or other recipients proved to be triatomines. Notification by local inhabitants proved to be the most effective form of surveillance, with the highest triatomine detection rate. During 1985-87 a total of 785 Gómez Núñez boxes were installed inside houses, of which 698 were inspected, 51 of which were positive. The majority of the positive boxes contained vestiges (feces $92 \%$, exuviae $4 \%$ ), while only two contained triatomines. The efficacy of calendars was also evaluated. During 1986-88 a total of 743 units were installed, of which 661 were examined, with only 26 positive for triatomine feces ${ }^{89}$.

The Peridomiciliary Surveillance Units (PSUs) set up in 1988 initially used a device consisting of a plastic bottle with several orifices and containing paper, placed inside chicken houses. During a pilot project 73 PSUs were set up. Some 38 were inspected, of which 13 were positive. The plastic bottles have now been replaced with bamboo devices.

The Minimum Surveillance Unit (MSU) was also introduced in 1988, consisting of a calendar containing information on Chagas' disease to which a plastic bag is attached. This was the surveillance system used from 1988 to 1992 . During this period 386 specimens of $T$. sordida were detected, of which only 5 were infected, while during the initial phase (1975-79) the natural infection rate was $54.5 \%$, no doubt due to the dense prevailing $T$. infestans population in domiciles in the area, which had not been submitted to chemical spraying ${ }^{8}$.

In 1988, evaluation of the impact of vector control on human infection using serological testing in 356 children under 8 years of age and thus born after the mass insecticide attack showed that only $8(2.2 \%)$ were reactive, while in 855 children investigated before the insecticide attack, 137 (15.5\%) were reactive $^{8}$.

The county of Mambaí was reapportioned in 1992, and the study area thus now covers two counties (Mambaí and Buritinópolis), with a population initially estimated at 8,521 for purposes of planning the operations involved in the new evaluation reported herein (IBGE 1998).

The overall objective of this new evaluation was to determine the impact of vector control measures on Chagas' disease transmission, based on entomological indicators and infection prevalence in the human population (the object of study reported in another article) in a longitudinal study area kept under long-term surveillance based on community participation. The specific objectives of the entomological evaluation were to determine: i) the risk of domiciliation of Triatoma sordida and other potential vector species for Chagas' disease in an area originally infested with $T$. infestans and submitted to domiciliary chemical spraying and maintained under entomological surveillance and ii) the sensitivity of instruments for the detection of triatomines (calendars-sensors) as compared to vector notification by the local populace and active search by institutional personnel in an area with a very low density of domiciliated triatomines.

\section{MATERIAL AND METHODS}

Entomological investigation was performed using active search with the man-hour technique and covering all the existing domiciliary units (DUs), their annexes or outbuildings and any other possible shelters for triatomines in the peridomicile (permanent or temporary artificial ecotopes), without the use of chemical insectifuges. The census was justified by the fact that coverage of control measures had been only partial for a long time, oriented by previous findings, and that in the meantime new dwellings had been built while other houses had been replaced or demolished.

The search was performed by experienced personnel, with time controlled to one hour/DU, during which time an entomological forceps was used to capture all specimens of known triatomines, which were kept in separate containers for the intra- and peridomicile groups.

Field personnel were instructed to begin the search inside the house, focusing on places with the most 
frequent findings, such as under mattresses and in nests or close to resting places for animals, as well as dividing total capture time between the intra- and peridomicile areas. In practical terms the time spent in each of the settings depended on the greater or lesser probability of finding triatomines in each of them, which depended in turn on the vector species present, the type of construction of the house and outbuildings, and the existing food sources. Division of time was thus based on these variables and was decided by the person performing the capture. A mean time of 15 minutes each was reserved for inspection of the intra- and peridomicile, while the remaining 30 minutes were set aside for the place where the capture had been most productive on initial inspection.

Captured specimens were classified by species and stage and submitted to fresh-mount microscopic examination of the intestinal content. The initial orientation was that for species other than Triatoma infestans, the material should be collected for precipitin assays to identify feeding sources. Depending on the number of specimens captured in each house, the number of tests was limited to a maximum of 10 specimens. However, when intradomiciliary colonies were found it was recommended not to enforce this limit.

To study the food sources, the stomach content of the triatomines was analyzed using the precipitin technique in capillary tubes ${ }^{21}$ as modified by Lorosa et al $^{10}$, using the stomach content directly in the test tube containing $0.85 \%$ saline solution. This material was left for 12 hour at a temperature of $4-8^{\circ} \mathrm{C}$ and was centrifuged the following day; the supernatant was tested for the following anti-sera and respective titers: human, dog, horse, goat, cow, pig, rodent, opossum, sheep, lizard, and toad ${ }^{10} 11$.
Positive DUs were sprayed with residual insecticides (synthetic pyrethroids). The initial indication when Triatoma infestans was found was to do full spraying of the intra- and peridomicile. For Triatoma sordida and other species that were identified, the dwelling was only to be sprayed if intradomiciliary colonies were found.

Even though it was considered a remote possibility, according to instructions if $T$. infestans was captured frequently, full spraying of infested sites was to be performed. Another situation which was also considered improbable and that was to receive special treatment was the existence of colonies of secondary species (most probably $T$. sordida) inside some houses. Any DU with this species was also to be sprayed, even if the infestation was only peridomiciliary, in order to reduce the pressure to invade the houses. Although the probability of one of these situations was low, if it did occur it was to be identified by examining the data collected at the end of the entomological survey, and the decision would then be made as to whether to expand the insecticide spraying.

Once the active search was concluded, the triatomine detection devices were then installed or reinstalled. The calendars were redesigned to adjust them to the new epidemiological situation in the area. Calendars are supposed to be examined every three months during a year of follow-up. At the end of this period the results will be evaluated based on the indicators proposed by $\mathrm{PAHO} / \mathrm{WHO}$, both for measuring and evaluating the results and for validating the entomological surveillance measures for Chagas' disease (PAHO/HPC/HCT/94-20).

\section{RESULTS}

The entomological survey covered $100 \%$ of the locations in the counties, with $89.3 \%$ of all known domiciliary units inspected. The survey's scope indicates a high level of reliability in the results.

Of all 67 existing and inspected locations in the counties, presence of triatomines was demonstrated in 48 , representing a $71.6 \%$ dispersion rate (Table 2 ). Infestation was markedly peridomiciliary. Of all the 293 infested domiciliary units, triatomines were captured inside the houses in only 25 cases. DU infestation rates were 8.7 for Mambaí and 12.1 for Buritinópolis, with intradomiciliary rates of only 0.7 and $1.2 \%$, respectively (Table 3 ).

Table 2. Number of existing locations inspected and positive for triatomines and dispersion rate in the counties of Mambaí and Buritinópolis, Goiás State, Brazil. 1999.

\begin{tabular}{lcccc}
\hline & \multicolumn{4}{c}{ Locations } \\
\cline { 2 - 5 } County & existing & inspected & positive & dispersion (\%) \\
\hline Mambaí & 33 & 33 & 23 & 69.7 \\
urban area & 1 & 1 & 1 & 100.0 \\
rural area & 32 & 32 & 22 & 68.7 \\
Buritinópolis & 34 & 34 & 25 & 73.5 \\
$\quad$ urban area & 1 & 1 & 1 & 100.0 \\
$\quad$ rural area & 33 & 33 & 24 & 72.2 \\
\hline Total & 67 & 67 & 48 & 71.6 \\
\hline
\end{tabular}

Chemical spraying was conducted selectively for each infested domiciliary unit, since there was no capture of $T$. infestans and no intradomiciliary colonies were found of other vector species. A total of 143 DUs were sprayed in Buritinópolis and 124 in Mambaí. There was thus a pendency in the order of $9.9 \%$. The insecticide used was cypermethrine wettable powder, 40.0 . 
Table 3 - Number of existing, inspected, and triatomine-positive domiciliary units and infestation rates according to capture site in the counties of Mambaí and Buritinópolis, Goiás State, Brazil. 1999.

\begin{tabular}{lcccccc}
\hline & \multicolumn{5}{c}{ Domiciliary units } \\
\cline { 2 - 6 } County & \multicolumn{5}{c}{ positive } & \multicolumn{2}{c}{ infestation (\%) } \\
\cline { 2 - 6 } & existing & inspected & ID* & PD $^{* *}$ & ID & PD \\
\hline Mambaí & 1,682 & 1,486 & 11 & 130 & 0.7 & 8.7 \\
urban area & 986 & 901 & 4 & 13 & 0.4 & 1.4 \\
rural area & 686 & 585 & 7 & 117 & 1.2 & 20.0 \\
Buritinópolis & 1,258 & 1,140 & 14 & 138 & 1.2 & 12.1 \\
$\quad$ urban area & 602 & 526 & 2 & 47 & 0.4 & 8.9 \\
rural area & 656 & 614 & 12 & 91 & 1.9 & 14.8 \\
\hline Total & 2,940 & 2,626 & 25 & 268 & 0.9 & 10.2 \\
\hline
\end{tabular}

*intradomicile, ${ }^{* *}$ peridomicile

A total of 485 triatomine specimens were captured, including 185 in Mambaí and 300 in Buritinópolis. Of the five vector species found in the area, including both counties, Triatoma sordida was the only one for which a few specimens were found in the intradomicile, with no clear evidence of more extensive colonization.
Presence of other species (Triatoma pseudomaculata, Triatoma costalimai, Panstrongylus megistus, and Rhodnius neglectus) was episodic and extremely rare as compared to T. sordida, the species identified in $97.3 \%$ of the captures (Tables 4 and 5).

Triatoma sordida was also the only species proven to be naturally infected with Trypanosoma cruzi, or cruzi type,

Table 4 - Number of triatomine specimens captured according to species, stage, and capture site in the county of Buritinópolis, Goiás State, Brazil. 1999.

\begin{tabular}{|c|c|c|c|c|c|}
\hline \multirow[b]{3}{*}{ Species } & \multicolumn{4}{|c|}{ Number specimens } & \multirow[b]{3}{*}{ Total } \\
\hline & \multicolumn{2}{|c|}{ intradomicile } & \multicolumn{2}{|c|}{ peridomicile } & \\
\hline & adults & nymphs & adults & nymphs & \\
\hline T. sordida & 4 & 5 & 110 & 174 & 293 \\
\hline T. costalimai & 0 & 0 & 0 & 5 & 5 \\
\hline R. neglectus & 0 & 0 & 2 & 0 & 2 \\
\hline
\end{tabular}

Table 5 - Number of triatomine specimens captured according to species, stage, and capture site in the county of Mambaí, Goiás State, Brazil. 1999.

\begin{tabular}{lccccc}
\hline & \multicolumn{4}{c}{ Number specimens } & \\
\cline { 2 - 5 } Species & \multicolumn{2}{c}{ intradomicile } & \multicolumn{2}{c}{ peridomicile } & Total \\
\cline { 2 - 5 } & adults & nymphs & adults & nymphs & 179 \\
\hline T. sordida & 2 & 5 & 63 & 109 & 2 \\
T. seudomaculata & 0 & 0 & 2 & 0 & 2 \\
P. megistus & 0 & 0 & 1 & 1 & 1 \\
R. neglectus & 0 & 0 & 1 & 0 & 1 \\
T. costalimai & 1 & 0 & 0 & 0 & \\
\hline
\end{tabular}

since the intestinal content was only examined in wet mounts. Infection rates were low but not negligible, at least in Buritinópolis, where the rate was $4.4 \%$ of the specimens examined (Table 6). The infection rate in Mambaí was $1.4 \%$ (Table 7 ).

Table 6 - Number of triatomine specimens captured, examined, and positive for Trypanosoma (type) cruzi in the county of Buritinópolis, Goiás State, Brazil. 1999.

\begin{tabular}{lrccc}
\hline & \multicolumn{3}{c}{ Number specimens } & \\
\cline { 2 - 4 } Species & captured & examined & positive & Infection rate (\%) \\
\hline T. sordida & 293 & 204 & 9 & 4.4 \\
R. neglectus & 2 & 0 & - & - \\
T. costalimai & 5 & 5 & 0 & 0.0 \\
\hline
\end{tabular}

However, the most significant result in the entomological survey per se was the complete absence of Triatoma infestans; the domiciliated vector species in the past (Table 1$)^{9}$, which was proven to have been completely eliminated. This observation confirms previous results from routine program operations by the 
Table 7 - Number of triatomine specimens captured, examined, and positive for Trypanosoma (type) cruzi in the county of Mambaí, Goiás State, Brazil, 1999.

\begin{tabular}{lcccc}
\hline & \multicolumn{3}{c}{ Number specimens } & \\
\cline { 2 - 4 } Species & captured & examined & positive & Infection rate (\%) \\
\hline T. sordida & 179 & 140 & 2 & 1.4 \\
T. pseudomaculata & 2 & 2 & 0 & 0.0 \\
P. megistus & 2 & 2 & 0 & 0.0 \\
R. neglectus & 1 & 1 & 0 & 0.0 \\
T. costalimai & 1 & 1 & 0 & 0.0 \\
\hline
\end{tabular}

National Health Foundation (FUNASA), in addition to the fact that no notifications of Triatoma infestans were made by the local populace.

In relation to feeding sources, the first observation was the wide variety of positive reactions to different anti-sera (Table 8), proving the great ecological valence of the species identified, in particular Triatoma sordida, since $97.3 \%$ of the specimens captured belonged to this species.
There was a clear preference for birds as the main food source (45\%), which is in agreement with the high ornithophilia of $T$. sordida, while only $2.8 \%$ of samples reacted with human anti-serum, demonstrating the species' low anthropophilia.

There were numerous cases $(18.5 \%)$ with multiple food sources, with two and even three reactive anti-sera (Table 9). Table 8 - Survey of food sources for triatomines captured in the counties of Mambaí
and Buritinópolis, Goiás State, Brazil. Number and percentage of positive reactions by anti-serum. 1999.

\begin{tabular}{lrr}
\hline & \multicolumn{2}{c}{ Positive reactions } \\
\cline { 2 - 3 } Food source & $\mathrm{nr}$ & \multicolumn{1}{c}{2.8} \\
\hline Man & 9 & 45.0 \\
Bird & 222 & 26.0 \\
Rodent & 128 & 14.0 \\
Dog & 69 & 9.9 \\
Opossum & 49 & 1.8 \\
Horse & 9 & 1.0 \\
Cow & 5 & 0.4 \\
Goat & 2 & 100.0 \\
\hline Total & 493 &
\end{tabular}

Table 9 - Survey of food sources for triatomines captured in the counties of Mambai and Buritinópolis, Goiás State, Brazil. Number of triatomine specimens with positive reactions to multiple anti-sera. 1999.

\begin{tabular}{lccc}
\hline & \multicolumn{2}{c}{ Total positive reactions } & Total multiple reactions \\
\cline { 2 - 4 } Positive reactions & $\mathrm{nr}$ & \multicolumn{1}{c}{$\%$} & $\%$ \\
\hline Reactive to 2 food sources & 81 & 16.4 & 89.0 \\
Reactive to 3 food sources & 10 & 2.0 & 11.0 \\
Total multiple reactions & 91 & 18.5 & 100.0 \\
Total positive reactions & 493 & 100.0 & - \\
\hline
\end{tabular}

The predominant multiple reactions were to domestic animals. Another important observation was the frequency (among multiple reactions) of reactions to dogs and especially to opossums, synanthropic animals which are thus highly relevant to the relationship between the wild and domiciliary transmission cycles for Chagas' disease (Table 10).

\section{DISCUSSION}

Based on the results of the entomological survey, the odds of domiciliary transmission of Chagas' disease in the study area are extremely low. Triatoma infestans had been eliminated, while the native species present there show little or no invasive capacity into human housing. Rather than capacity, a more appropriate term might be necessity.

It has been definitely established, and the current data reaffirm, that Triatoma sordida only tends to occupy the intradomicile when food sources in the peridomicile have been exhausted, either because the triatomine 
Table 10 - Survey of food sources for triatomines captured in the counties of Mambaí and Buritinópolis, Goiás State, Brazil. Number of triatomine specimens of anti-sera. 1999.

\begin{tabular}{lrr}
\hline & \multicolumn{2}{c}{ Specimens } \\
\cline { 2 - 3 } Anti-sera & $\mathrm{nr}$ & $\%$ \\
\hline Man/bird & 6 & 6.6 \\
Mird/rodent & 23 & 25.3 \\
Bird/opossum & 16 & 17.6 \\
Bird/dog & 16 & 17.6 \\
Dog/rodent & 6 & 6.6 \\
Rodent/opossum & 5 & 5.5 \\
Bird/horse & 5 & 5.5 \\
Goat/cow & 2 & 2.2 \\
Dog/cow & 1 & 1.1 \\
Dog/opossum & 1 & 1.1 \\
Bird/dog/rodent & 6 & 6.6 \\
Bird/dog/opossum & 3 & 3.3 \\
Dog/rodent/opossum & 1 & 1.1 \\
\hline Total & 91 & 100.0 \\
\hline
\end{tabular}

population has increased excessively or there has been a reduction in the peridomiciliary food supply ${ }^{419}$.

As for other vector species, the fact that specimens were detected so rarely and the data on geographic distribution of these potential vectors indicate that there is no risk of their transmitting the disease in the domiciliary setting within the study area ${ }^{6} 18$. The center of endemicity for Triatoma pseudomaculata is in the semi-arid region of the Brazilian Northeast, and the Mambaí area is close to the southernmost edge of its dispersion area. Panstrongylus megistus, which at least in the past was an important vector in more humid areas such as those in which the Atlantic Forest has been most radically devastated, is only present in the Mambaí area in ciliary forests, along bodies of water. Among the species captured, only Rhodnius neglectus, in addition obviously to $T$. sordida, is a widely dispersed triatomine in the savannas (cerrados) ${ }^{7}$ and was initially thought to pose a potential role in the direct transmission of the disease to humans following the elimination of Triatoma infestans ${ }^{5}$. However, this has not proven to be the case, based on routine control operation data in Goiás State and the current study.

Considering the study indicators, one particular observation calls attention, i.e., the very high dispersion rates: $69.7 \%$ in Mambaí and $71.6 \%$ in Buritinópolis. However, this was to be expected, given the known extensive distribution of Triatoma sordida in the natural environment in the region ${ }^{7}$. Finding specimens of this species with greater or lesser density in the peridomicile is thus absolutely predictable. Infestation rates in outbuildings, especially in rural locations, thus do not pose a major risk, since what matters from the point of view of transmission is intradomiciliary infestation as well as indoor colonization. If these conditions are not met, transmission will only be accidental. These conditions actually reflect the fact that in order for Chagas' disease transmission to occur on what could be called a regular basis, it is absolutely indispensable to have continuous exposure of humans to the infected vector ${ }^{16}$

Besides colonization being rare, although natural infection is not negligible, in absolute terms it is not very important. When there are only 11 infected $T$. sordida specimens, almost exclusively in the peridomicile and not colonizing houses, the possibility of transmission to humans is almost nil.

In addition, the vector density (a measurement made possible by the man-hour inspection technique) was also low, i.e., 485 triatomines captured in the 2,626 domiciliary units inspected.

According to the results of the precipitin assays in the food source survey, in addition to humans being an infrequent food source for triatomines (as expected because of the rare presence of the vector inside houses), the species existing in the area display extensive feeding eclecticism. Furthermore, since birds are the preferred food source and are refractory to $T$. cruzi infection, vector infection rates tend to remain low as long as the current food supply conditions are not altered.

The final evaluation of the control and surveillance measures in Mambaí, and now also in Buritinópolis, is highly positive. Figures 1 and 2, with the historical data and current infestation rates for Triatoma infestans and T. sordida, show that: the area;

1) Triatoma infestans has been eliminated from

2) the elimination of Triatoma infestans has not led to its replacement by another vector in the intradomicile, as has been observed in some other localized and still incipient situations ${ }^{117}$;

3) there was even a reduction in the intradomiciliary $T$. sordida population, which can be explained by environmental changes and permanent surveillance measures.

The risk of vector transmission of Chagas' disease in the counties of Mambaí and Buritinópolis is practically 


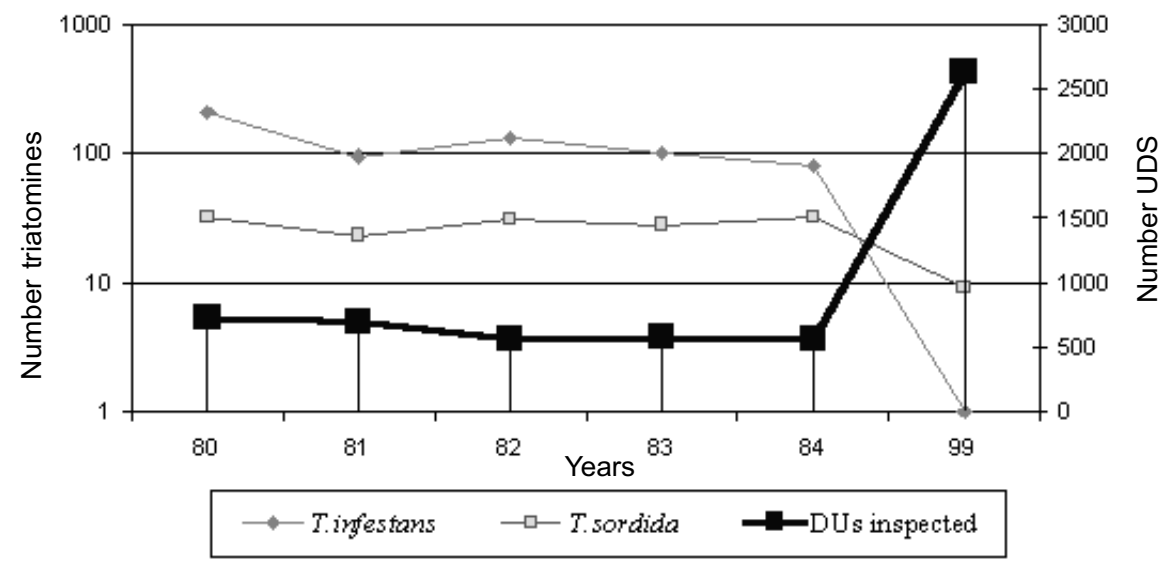

Figure 1 - Triatoma infestans and T. sordida specimens captured in the intradomicile in the country of Mambaí*, Goiás State, Brazil. 1980-84 and 1999.

* Data for 1999, include country of Buritinópolis, subdivided from Mambaí

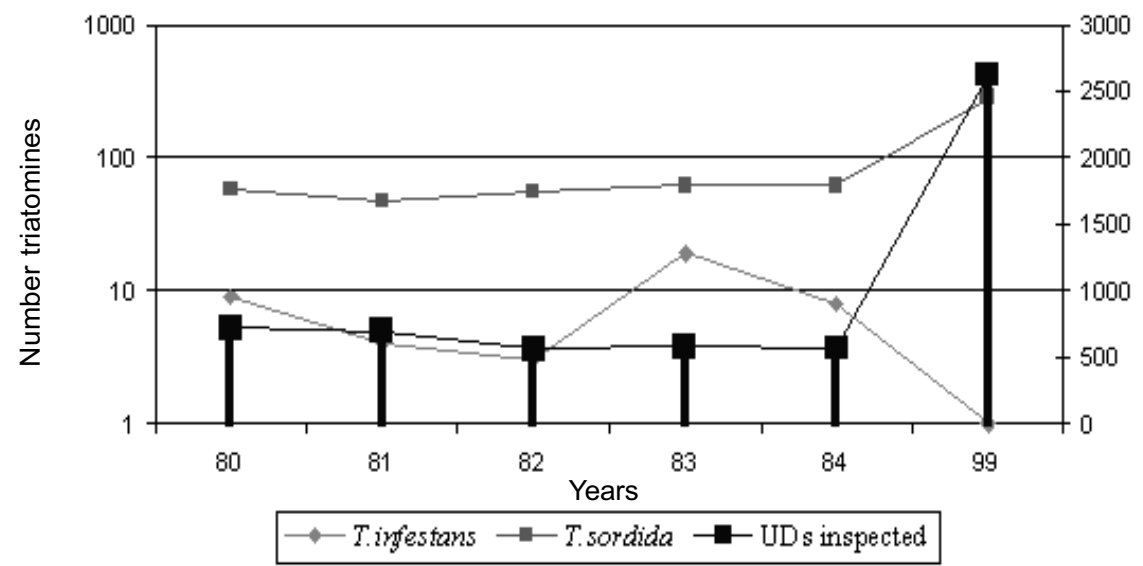

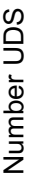

Figure 2 - Triatoma infestans and T. sordida specimens captured in the peridomicile in the country of Mambaí, Goiás State, Brazil. 1980-84 and 1999.

*Data for 1999 include the country of Buritinópolis, subdivided from Mambaí

non-existent, but it is necessary to maintain surveillance activities in order to ensure the early detection of any possible (albeit highly improbable) domiciliary colonization by existing native species. In addition, it is possible for Triatoma infestans to reenter the area, and this may be the greatest risk, considering this species' persistence in some geographically close areas, like southeastern Tocantins State or western Bahia State ${ }^{20}$.

Based on the results and accumulated experience, the prevailing surveillance model should be maintained. The difficulty in sustaining the model over time is that transmission has been interrupted, and in the absence of the disease (which by itself is not very visible, based on its peculiar clinical characteristics), the population's interest depends on persistent work and mobilization by local health services, with a new content, adjusted to the new epidemiological situation.

The results achieved through the work in the Mambaí-Buritinópolis area and reported in the above article are due to a great extent to the initiative of Dr. Philip Marden and his collaborators Dr. Marco Túlio Garcia-Zapata and Domingos das Virgens.

\section{REFERENCES}

1. Almeida CE, Nunes IM, Vinhaes MC, Almeida JR, Silveira C, Costa J. Monitoramento do processo sinantrópico e do potencial vetorial de Triatoma rubrovaria (Blanchard,1843) (Hemiptera, Reduviidae, Triatominae) no Estado do Rio Grande do Sul. In: I Bienal de Pesquisa da Fundação Oswaldo Cruz. p.181, 1988.
2. Castro $\mathrm{CN}$. Influência da parasitemia no quadro clínico da doença de Chagas. Resvista de Patologia Tropical 9: 73-136, 1980.

3. Castro CN. Estudo longitudinal da parasitemia e sua correlação com a evolução clínica. Doctoral thesis, Universidade Federal de Minas Gerais, Belo Horizonte, p. 161, 1993. 
4. Diotaiuti L, Riberio De Paula O, Falcão PL, Dias JCP. Avaliação do programa de controle vetorial da doença de Chagas em Minas Gerais, Brasil, com referência especial ao Triatoma sordida. Boletín de la Oficina Sanitaria Panamericana 118: 211-9, 1995.

5. Diotaiuti L, Silveira AC, Matos CAS. Estudo do Rhodnius neglectus Lent, 1954 em ecótopos silvestres no Estado do Goiás, Brasil. In: Resumos do XXI Congresso da Sociedade Brasileira de Medicina Tropical, São Paulo. p. 33, 1985.

6. Forattini OP. Biogeografia, origem e distribuição da domiciliação de triatomíneos no Brasil. Revevista de Saúde Pública de São Paulo 14: 265-299, 1980.

7. Forattini OP, Barata JMS, Santos JLS, Silveira AC. Hábitos alimentares, infecção natural e distribuição de triatomíneos domiciliados na região central do Brasil. Revista de Saúde Pública de São Paulo 6: 171-204, 1982.

8. Garcia-Zapata MT, Marsden PD. Enfermedad de Chagas: control y vigilancia con insecticidas y participación comunitária en Mambaí, Goiás, Brasil. Boletín de la Oficina Sanitaria Panamericana 116: 97-110, 1994.

9. García-Zapata MT, Marsden PD, Domingos V, Penna R, Soares V, Brasil IA, Castro CN, Prata A, Macêdo V. O controle da transmissão da doença de Chagas em Mambaí-Goiás, Brasil (1982-1984). Revista da Sociedade Brasileira de Medicina Tropical 19: 219-225, 1986.

10. Lorosa ES, Andrade RE, Santos SM, Pereira CA. Estudo da infecção natural e da fonte alimentar do Triatoma sordida (STAL, 1859), (Hemíptera-Reduviidae) na região norte de Minas Gerais, Brasil, através da reação de Precipitina. Entomologia y Vectores 5: 13-22, 1998.

11. Lorosa ES, Andrade RE, Santos SM, Pereira CA, Vinhaes MC. Estudo do comportamento alimentar de algumas espécies de triatomíneos com auxilio da técnica de precipitinas. Entomologia y Vectores 6: 112-125, 1999.

12. Marsden PD. The control of Chagas' Disease in Mambaí, Brazil: the initial phases. Infection Control 2: 466-470, 1981.
13. Marsden PD, Penna R. A 'vigilance unit' for households subject to triatomine control. Transactions of the Royal Society of Tropical Medicine and Hygiene 76: 790-792, 1982.

14. Marsden PD, Virgens D, Castro CN, Brasil IP, Ferreira R, Silveira AC, Matos CAS, Macedo V, Prata A. The control of Chagas' disease transmission in Mambaí, Goiás-Brazil (1980-1981). Revista da Sociedade Brasileira de Medicina Tropical 16: 189-195, 1983.

15. Marsden PD, Virgens D, Magalhaes I, Tavares-Neto J, Ferreira $\mathrm{R}$, Costa $\mathrm{CH}$, Castro CN, Macêdo V, Prata A. Ecologia doméstica do Triatoma Infestans em Mambaí, Goiás-Brasil. Revista do Instituto de Medicina Tropical de São Paulo 24: 364-373, 1982.

16. Rabinovich JE, Wisnivesky-Colli C, Solarz ND, Gurtler RE. Probability of transmission of Chagas disease by Triatoma infestans (Hemiptera: Reduviidae) in an endemic area of Santiago del Estero, Argentina. Bulletin World Health Organization 68: 737 746, 1990.

17. Silveira AC, Diotaiuti L, Neiva E, Matos CAS, Elias M. Domiciliação de Rhodnius neglectus Lent, 1954, no Estado de Goiás, Brasil. In: Resumos da X Reunião Anual sobre Pesquisa Básica em Doença de Chagas. Caxambu. Resumo v. 16, 1983.

18. Silveira AC, Feitosa VR, Borges R. Distribuição de triatomíneos capturados no ambiente domiciliar, no período de 1975-83, Brasil. Revista Brasileira de Malariologia. Doenças Tropicais 36: 15-312, 1984.

19. Silveira AC, Souza PC, Silveira Netto HV. Importância de espécies secundárias de triatomíneos na transmissão domiciliar da doença de Chagas no Triângulo Mineiro e Alto Paranaíba. In: XXIX Congresso da Sociedade Brasileira de Medicina Tropical. Revista da Sociedade Brasileira de Medicina Tropical 26 (supl I): 200, 1993.

20. Silveira AC, Vinhaes MC. Elimination of vector-borne transmission of Chagas' disease. Memórias do Instituto Oswaldo Cruz, 94 (supl I): 405-411, 1999.

21. Siqueira AF. Estudos sobre a reação da precipitina aplicada à identificação de sangue ingerido por triatomíneos. Revista do Instituto de Medicina Tropical de São Paulo 2: 41-53, 1960. 